\title{
Türkülerin Işığında Kürdî Makamının Yeniden Ele Alınması
}

\section{Reevaluation of the Kürdî Makam in the Light of Turkish Folk Songs}

\author{
Kubilay YILMAZ ${ }^{1}$
}

'Dr. Öğr. Üyesi, Sivas Cumhuriyet Üniversitesi, Türk Müziği Devlet Konservatuvarı, Türk Müziği Bölümü, Sivas, Türkiye

ORCID: K.Y. 0000-0001-9317-3549

\section{Sorumlu yazar/Corresponding author:} Kubilay YILMAZ,

Sivas Cumhuriyet Üniversitesi, Türk Müziği Devlet Konservatuvarı, Türk Müziği Bölümü, Sivas, Türkiye

E-posta/E-mail: Kubilaylmz@hotmail.com

Başvuru/Submitted: 12.10.2021

ilk Revizyon/Revision Requested: 28.11.202 Son Revizyon/Last Revision Requested: 01.12.2021

Kabul/Accepted: 02.12.2021

Online Yayın/Published Online: 08.12.2021

Atıf/Citation: Yilmaz, K. (2021). Türkülerin ışığında Kürdî makamının yeniden ele alınması. Konservatoryum - Conservatorium, 8(2), 281-312.

https://doi.org/10.26650/CONS2021-1008611 öz

Türk halk müziği repertuvarındaki türkülerden yola çıkılarak Kürdî makamının yeniden ele alındığı ve elde edilen verilerin güncel nazari bilgilerle karşılaştırılarak yorumlandığı bu çalışmada öncelikle TRT Türk halk müziği repertuvarı incelenerek Kürdî makamında olduğu tespit edilen 20 örnek türkü seçilmiştir. Seçilen eserler öncelikle geleneksel yöntem ile analiz edilmiştir. Bu süreçte eserin dizisi, güçlü perdesi ve kalışları gibi unsurlar belirlenmiştir. Güçlü perde belirlenirken öncelikle söz bölümündeki ilk kalışlara ve önemli kalış noktalarına bakılmış; kalışların net bilgi vermediği durumlarda ise MIDI (Musical Instrument Digital Interface) analiz raporundaki verilerden yardım alınmıştır. Dizinin belirlenmesinde de güçlü perde merkez kabul edilip bu perdenin üstündeki ve altındaki çeşniler dikkate alınmıştır. Geleneksel yöntem ile analiz aşamasından sonra bilgisayar destekli analiz sürecine geçilmiş; bu süreçte ilk olarak örnek eserler Finale 2014 adlı nota yazım programıyla tekrardan yazılıp yine bu program aracılığıyla MIDI formatına dönüştürülmüştür. MIDI dosyaları, Seyr-i MIDI isimli program aracılığıyla analiz edilerek raporlar oluşturulmuştur. İki farklı analiz sonuçlarının birlikte yorumlanması sonucunda; kalışların önem derecesi, güçlü perde ve dizinin oluşumu başta olmak üzere bazı konularda bu araştırma verileriyle Arel-Ezgi nazariyesini temel alan veya Türk halk müziğinde diziler konusuna değinen hemen her kaynaktaki Kürdî makamı ile ilgili bilgilerin önemli ölçüde farklılık gösterdiği tespit edilmiştir.

Anahtar Kelimeler: Kürdî makamı, MIDI analizi, makam analizi, türkü

\section{ABSTRACT}

The main purpose of this study is reevaluate the Kürdî makam and interpret the data in view of current theoretical knowledge. After examining the folk songs in the TRT Turkish folk music repertoire, a total of 20 sample folk songs determined to be in Kürdî makam were selected. The selected works were first analyzed using the conventional method. In this process, elements such as the scale, dominant pitch, and phrase endings of the works were investigated. While determining the dominant pitch, end of the first phrase of the work in the lyrical section and important phrase endings were reviewed. In cases where the phrase endings of the work did not provide clear information, the data in the Musical Instrument Digital Interface (MIDI) analysis report were used. In determining the scale, the dominant pitch was accepted as the center note 
and the tones above and below this pitch establish the range. The analysis phase using the conventional method was continued using computer aided analysis. In this process, the sample works were rewritten in the Make Music Finale 2014 program and converted into MIDI format. The MIDI files were analyzed through a program called Seyr-i MIDI and reports were created. The results of the two different analyses reveal that the information about the Kürdî makam presented in almost every source based on Arel-Ezgi theory or affiliated with the scales in Turkish folk music differs significantly from the actual data in terms of the level of importance of phrase endings, dominant pitch, and the formation of scale.

Keywords: Kürdî makam, MIDI analysis, makam analysis, folk song

\section{EXTENDED ABSTRACT}

For a certain period of time, a number of terms such as ayak and hava have been used to name folk songs melodically instead of makam. This ongoing erroneous situation has resulted in gradual distinction of the two major genres commonly coined as folk music and Turkish classical music today, which differ over time in terms of usage, instruments, and style. When the tonality and notational nuances are added to the makam-ayak contradiction in melodic naming, these two genres have inevitably come to be perceived as distinct from one another by some scholars. Toward the end of the twentieth century, though the concept of makam began to be used more widely in the melodical nomenclature of folk songs, researchers were cautious since some folk songs were not consistent with well-known definitions of makam. One of the primary causes of this situation is that many folk songs consisting of only a few pitches do not fully meet the requirements for makam according to the Arel-Ezgi theory. Specifically, as expounded by the Arel-Ezgi theory, there is a requirement of a scale combining at least one quartet and a chain of fifths and the concept of seyir formed by improvising in this scale according to certain rules.

When the folk songs are examined, it is obvious that there are many works consisting of only a few notes. Folk songs have survived up to present day with hundreds of years of cultural heritage. It is unreasonable to exclude these folk songs when defining the melodic structure of Turkish music, since the most important building blocks of the melodic structure of Turkish music can be found in folk songs. Therefore, it is clear that Arel-Ezgi theory, failing to explain the melodic structure of many folk songs, is not fully sufficient to describe Turkish makam music. In order to explain the folk songs that are not covered by the theory in question, it will be useful to base our definition of makam on the theoretical music books, where the concept of makam is explained with several voices. There is no pitch limitation in these definitions. Therefore, any makam can be explained with three or four pitches. For instance, Dügâh, Dik Kürdî, Nim Hicaz, and Neva pitches are sufficient to be accepted as Hicaz makam as in the case of Eviç, Rast, Dügah, and Segâh pitches to be in the Rast makam. 
The main purpose of this study is to reevaluate the Kürdî makam and interpret the data in view of current theoretical knowledge. There are also folk songs consisting of only 5 to 6 pitches among the sample works. The presence of distinctive traits revealing the identity of the Kürdî makam in these works is deemed sufficient for acceptance of the relevant makam. However, the terminology of Arel-Ezgi theory is used as often as possible during the examination of the sample works. The failing aspects of this theory have been highlighted with many studies in the literature. Despite that, the reason why the Arel-Ezgi theory is preferred is that there is no other widely referenced and accepted theory whose terminology is well-known in music education institutions.

During the procedure, the TRT Turkish folk music repertoire was examined, and a total of 20 sample folk songs belonging to 18 different regions, which were determined to be in the Kürdî makam, were randomly selected. The selected works were first analyzed using the conventional method. In this process, elements, such as the tonic pitch of the work, its structure, sensibility, expansion, ends of phrase, dominant pitch, and scale, were investigated. While determining the dominant pitch, end of the first phrase of the work in the lyrical section and important phrase endings were reviewed. In cases where the phrase endings of the work did not provide clear information, the data in the MIDI analysis report were used. In determining the scale, the dominant pitch was accepted as the center and the tones above and below this pitch were used to establish the range. The analysis phase using the conventional method was continued using computer aided analysis. In this process, the sample works were rewritten in the Make Music Finale 2014 program and converted into MIDI (Musical Instrument Digital Interface) format. MIDI files were analyzed through an analysis program called Seyr-i MIDI and reports were created.

The results of the two different analyses reveal that the information about the Kürdî makam presented in almost every source based on Arel-Ezgi theory or affiliated with the scales in Turkish folk music differs significantly with the actual data in terms of the level of importance of phrase endings, dominant pitch, and the formation of scale. 


\section{Giriş}

Türkülerin ezgisel adlandırılması konusunda makam kavramı yerine uzunca bir süre ayak, hava vb. terimler kullanılmıştır. Özbek, ayak teriminin makama karşılık geldiğini ifade eden Gültekin Oransay, Güray Taptık, Yücel Paşmakçı, Nida Tüfekçi, Mustafa Özgül, Şemsi Yastıman gibi sanatçı ve araştırmacıların beyanlarına yer verdiği çalışmasında özetle bu kullanımın yanlış olduğunu açıklamıştır (1987, s. 205). Kutluğ 'ayak' teriminin 1940'lı yıllara kadar bilinmediğini; Türkiye Radyo Televizyon kanallarının yayına başlamasıyla ayak teriminin halk müziğine mâl edilmeye başlandığını ancak bu durumun tam bir açıklık getirilmeden bir kavram karmaşası içinde devam edegeldiğini ifade etmiştir (2000, s. 503). Soysal ve Yürümez ise bu durumun Ziya Gökalp'e kadar dayanan ulus devlet politikaları ve sosyolojik tartışmalarda yer bulan birçok sebebinin bulunduğunu bildirmişlerdir (2020, s. 45). Sebebinin ne olduğu bir kenara, uzunca zaman süren bu hatalı durum, kullanım alanı, kullanılan çalgılar ve üslûp açısından ayrışma serüvenlerinin başlangıcı Gök Türkler dönemine kadar götürülen (Uçan, 2015, s. 30) ve günümüzde yaygın olarak 'halk müziği’ ve 'sanat müziği' diye adlandırılan iki türün gittikçe ayrışmasına zemin hazırlamıştır. Ezgi adlandırmalarındaki makam-ayak çelişkisine bir de ses sistemi ve notasyon farklılıkları da eklenince bu iki türün kimilerince birbirinden çok farklı iki müzik türü gibi algılanması kaçınılmaz olmuştur.

Yirminci yüzyılın sonlarına doğru türkülerin ezgisel adlandırılmasında makam kavramı daha çok yer edinmeye başlamışsa da bazı araştırmacılar, türkülerin bir kısmının bilinen makam tarifleri ile açıklanamaması yüzünden makam kavramını kullanma konusunda temkinli yaklaşmak durumunda kalmışlardır. Bu durumun en önemli sebeplerinden biri türkülerin birçoğunun Arel-Ezgi nazariyesine göre makam kavramını tam karşılamamasıdır. Çünkü bilindiği gibi Arel-Ezgi kuramında makamın oluşabilmesi için en az bir dörtlü ile beşlinin birleştiği bir diziye ve bu dizide belirli kurallara göre gezinmeyle oluşan seyir kavramına ihtiyaç vardır. Türkülere bakıldığında ise yalnızca birkaç notadan oluşan çokça eser olduğu görülmektedir.

Türkülerin yüzlerce yıllık aktarımla günümüze ulaştığı düşünüldüğünde Türk müziğinin ezgisel yapısı belirlenirken türkülerin göz ardı edilmesi düşünülemez. Zira Türk müziği ezgisel yapısının en önemli yapı taşları türkülerde bulunabilir. Dolayısıyla birçok türkünün ezgisel yapısını açıklayamayan Arel-Ezgi nazariyesinin, Türk makam müziğini anlatmada tam anlamıyla yeterli olmadığı görülmektedir. Söz konusu kuram ile açıklana- 
mayan, birkaç sesten oluşan türkülerin izahı için makam kavramının Nâsır Abdülbâkî Dede'nin Tedkîk ü Tahkîk isimli eserindeki şu ifadelere göre ele alınmasının faydalı olacağı düşünülmektedir; “[...] sonrakilerin ve sonrakilerin eskilerinin varsayımlarına göre makam, asıl unsurlarıyla işitildiğinde kendine özgü bir bütünlük, kişilik gösteren ve başka parçalara bölünmesi (başka şeye benzetilmesi) mümkün olmayan ezgidir” (Tura, 2006, s. 35). Görüleceği üzere bu tanımda ses/perde sınırlaması yoktur. Dolayısıyla üçdört perde ile bir makam açıklanabilir. Tıpkı Dügâh, Dik Kürdî, Nim Hicaz ve Neva perdelerinin Hicaz makamını; Eviç, Rast, Dügâh ve Segâh perdelerinin ise Rast makamını hissettirmede yeterli oldukları gibi.

Abdülbâkî Dede'nin ifadelerini destekler şekilde, makamların birkaç perde ile anlatıld1ğ farklı birçok edvardan örnek metinleri de Öztürk'ün çalışmasında bir arada bulmak mümkündür (2015, s. 10-19). Günümüz araştırmacılarından Melik Ertuğrul Bayraktarkatal (Bayraktarkatal ve Öztürk, 2012), Okan Murat Öztürk (2014a, 2014b, 2015; Öztürk, Beşiroğlu ve Bayraktarkatal, 2014), Sühan İrden (2015, 2020) ve Cenk Güray'ın (2017) makam olgusu üzerine yaptıkları çalışmalarda da yine birkaç perde ile makam kimliğinin oluşabilmesi durumuna örnek gösterilebilecek tespitler mevcuttur.

Türk halk müziği repertuvarındaki türkülerden yola çıkılarak Kürdî makamının yeniden ele alındığ 1 ve elde edilen verilerin güncel nazari bilgilerle karşılaştırılarak yorumlandığı bu çalışmada da örnek eserler içerisinde yalnızca 5-6 perdeden oluşan türküler de mevcuttur. Bu eserlerde Kürdî makam kimliğini gösteren belirgin çeşnilerin yer alması, ilgili makama atfedilmesi için yeterli görülmüştür. Bununla birlikte örnek eserlerin incelenmesi aşamasında mümkün olduğunca Arel-Ezgi kuramımın terminolojisi kullanılmıştır. Çokça çalışma ile bu nazariyenin aksayan yönleri vurgulanmıştır (Can, 2002; İrden, 2015, 2020; Kutluğ, 2000; Yarman, 2008; Özek, 2014; Öztürk, 2014a, 2014b, 2015; Öztürk, Beşiroğlu ve Bayraktarkatal, 2014; Tura, 2017; Yılmaz, 2019, 2020). Buna rağmen Arel-Ezgi nazariyesinin tercih edilmesinin sebebi, henüz bu nazariye kadar kabul gören bir kuramın olmaması; müzik eğitim kurumlarında yaygın olarak referans alınması; buna paralel olarak da söz konusu kuramın terminolojisinin yaygın olarak bilinmesidir.

\section{Yöntem}

Araştırmada, öncelikle TRT Türk halk müziği repertuvarı incelenerek Kürdî makamında olduğu tespit edilen 18 farklı yöreye ait toplam 20 örnek türkü random yöntemle seçilmiştir. Seçilen eserler öncelikle geleneksel yöntem ile analiz edilmiştir. Bu süreçte eserin karar 
perdesi, donanımı, yedeni, genişlemesi, kalışları, güçlü perdesi ve dizisi gibi unsurlar belirlenmiştir. Güçlü perde belirlenirken öncelikle söz bölümündeki ilk kalışlara ve önemli kalış noktalarına bakılmış; kalışların net bilgi vermediği durumlarda ise MIDI analiz raporundaki verilerden yardım alınmıştır. Dizinin belirlenmesinde de güçlü perde merkez kabul edilip bu perdenin üstündeki ve altındaki çeşniler dikkate alınmıştır. Geleneksel yöntem ile analiz aşamasından sonra bilgisayar destekli analiz sürecine geçilmiş; bu süreçte ilk olarak örnek eserler Finale 2014 adlı nota yazım programıla tekrardan yazilıp yine bu program aracılı̆̆ıgla MIDI (Musical Instrument Digital Interface) formatına dönüştürülmüştür. MIDI dosyaları, Seyr-i MIDI isimli analiz programı ${ }^{1}$ aracılığıyla analiz edilerek aşağıda bir örneği paylaşılan raporlar oluşturulmuştur. Bu raporlardaki dört sütundan soldan sağa doğru ilk sütunda perdenin eserde ne sıklıkla kullanıldığı; ikinci sütunda ne kadar süre yer aldığı; üçüncü sütunda Ayhan Zeren'in (2003, s. 97-98) formülüne göre etkinlik derecesi; dördüncü sütunda ise eserin toplam süresi içindeki oranı gösterilmektedir. Araştırmada, MIDI analiz raporları yorumlanırken öncelikle dördüncü sütunda yer alan 'toplam süreye oran' dikkate alınmıştır. Çünkü bir perdenin ne kadar sık kullanıldığından ziyade süre açısından hangi oranda kullanıldığının, o perdenin etkinlik derecesini gösteren en önemli unsur olduğu düşünülmektedir. Zeren de yukarıda bildirilen çalışmasında bu fikri destekler nitelikte beyanda bulunmuş; kullanım süreleri yakın olan perdelerden kullanım sıklığı az olanın daha etkin perde olduğunu ifade etmiştir. Çünkü bu durum, daha az sayıda kullanılan perdedeki kalış sürelerinin daha uzun olduğunu; dolayısıyla kalışın daha etkili ve anlamlı olduğunu göstermektedir. Bu çalışmada da 'toplam süreye oran' sütununda çok yakın değerlere sahip olan perdelerden hangisinin daha etkin kullanıldığını tespit etmek için üçüncü sütunda yer alan Zeren'in etkinlik derecesi formülüne bakılmıştır. Bu verilerin yanı sıra MIDI analiz raporlarında eserin genel seyir bölgesini görmek de mümkündür. Söz konusu raporlarda yer alan harfler ilgili notaların harf sembollerini, rakamlar ise kaçıncı oktavda yer aldıklarını belirtmektedir.

1 Doç Dr. Serdar ÇELIKK tarafından geliştirilen bu program, nota yazım programında yazılıp MIDI formatına dönüştürülen dosyaları analiz ederek herhangi bir perdenin kullanım sıklığı ve süresi, Ayhan Zeren'e göre etkinlik derecesi ve toplam süreye oranı gibi istatistiki bilgilerin yer aldığı raporlar oluşturmaktadır. 


\begin{tabular}{|c|c|c|c|c|c|c|c|}
\hline \multicolumn{2}{|c|}{ Perde $\sum \mathrm{Ni}$} & \multicolumn{2}{|c|}{ Perde $\Sigma$ ti } & \multicolumn{2}{|c|}{ Perde $\left.\left(\sum \mathrm{ti}\right)^{\wedge} 2\right) /\left(\sum \mathrm{Ni}\right)$} & \multicolumn{2}{|c|}{ Perde \% } \\
\hline E5 & 95.00 & E5 & 14.72 & E5 & 2.28 & E5 & 36.73 \\
\hline D5 & 62.00 & D5 & 7.85 & A4 & 1.14 & D5 & 19.59 \\
\hline F5 & 55.00 & F5 & 6.48 & D5 & 0.99 & F5 & 16.15 \\
\hline C5 & 35.00 & A4 & 4.89 & F5 & 0.76 & A4 & 12.21 \\
\hline G5 & 21.00 & C5 & 2.74 & G5 & 0.34 & C5 & 6.84 \\
\hline A4 & 21.00 & G5 & 2.67 & C5 & 0.21 & G5 & 6.65 \\
\hline A\#4 & 8.00 & A\#4 & 0.74 & A\#4 & 0.07 & A\#4 & 1.84 \\
\hline
\end{tabular}

Görsel 1. Örnek MIDI analiz raporu (Yılmaz, 2021).

Tek tek eser analizlerinden sonra incelenen tüm eserlere ait MIDI analiz raporlarının aritmetik ortalamalarını veren, eserlerin MIDI dosyalarının birleştirildikten sonra analiz edilmesi yöntemi uygulanmıştır. Böylelikle 20 eserin genel durumunu özetleyen, yukarıdaki örnek görselde olduğu gibi bir rapor oluşturulmuştur. Son olarak geleneksel ve bilgisayar destekli analiz sonuçları birlikte yorumlanmış ve elde edilen veriler ile güncel yazılı kaynaklarda yer alan Kürdî makamıyla ilgili bilgiler karşılaştırılmıştır.

\section{Bulgular}

Bu bölümde araştırmaya örnek seçilen 20 türkünün MIDI analiz raporlarından ve geleneksel yöntemle analizlerinden elde edilen bulgulara yer verilmiştir. Çalışmanın fazlaca hacimli olmaması adına eserlerin notaları paylaşılmamış; günümüzde türkü notalarına kolayca ulaşılabildiği de dikkate alınarak Tablo 1 ile sadece repertuvar numaraları ve yöre bilgileri paylaşılmıştır. Ayrıca karar perdesi, donanım, yeden gibi tüm eserlerde aynı olan unsurlara da her eserde ayrı ayrı yer verilmemiştir. İncelenen eserlerin hepsinin karar perdesi Dügâh; yeden kullanılan eserlerin hepsinin yedeni ise Rast perdesi olup hepsinin donanımında Kürdî perdesi yer almaktadır.

Tablo 1. İncelenen eserlerin listesi

\begin{tabular}{|l|c|c|}
\hline Eserin Adı & Rep. No. & Yöresi \\
\hline Ali gavak biçiyor & 1974 & Isparta \\
\hline Ayrıldım güler miyim & 3855 & Kırıkkale \\
\hline Bahçalarda barım var & 2879 & Iğdır \\
\hline Bu dağlarda bağ olmaz & 973 & Eskişehir \\
\hline Çamlar altına & 37 & Tokat \\
\hline Çek gemici gemileri & 552 & Antalya \\
\hline Çekmecemin anahtarı kemikten & 3179 & Silistre-Tutrakan \\
\hline
\end{tabular}




\begin{tabular}{|l|c|c|}
\hline Çıksam a Urumelinin düzüne & 4071 & Rumeli-Deliorman \\
\hline Edremit'in gelini & 4853 & Balıkesir-Edremit \\
\hline Eklemedir koca konak & 1009 & Aydın \\
\hline Elif dedim be dedim & 1210 & Kütahya \\
\hline Evlerinin önü yoldur & 3505 & Afyon-Emirdă̆ \\
\hline Hacel obası & 3275 & Sivas-Şarkışla \\
\hline Karahisar kalesi & 1621 & Afyonkarahisar \\
\hline Kayayı gırcı tuttu & 3521 & Çorum \\
\hline Kırmızı buğday & 441 & Manisa \\
\hline Köprünün altı testi & 216 & Muğla-Bodrum \\
\hline Kütahyanın pınarları & 1631 & Kütahya \\
\hline Sandık üstünde sandık & 1061 & Bergama \\
\hline Şu Köyceğiz yoları & 1327 & Köyceğiz-Ortaca \\
\hline
\end{tabular}

\section{Ali gavak biçiyor isimli esere ait bulgular}

\begin{tabular}{|c|c|c|c|c|c|c|c|}
\hline \multicolumn{2}{|c|}{ Perde $\sum \mathrm{Ni}$} & \multicolumn{2}{|c|}{ Perde $\sum \mathrm{ti}$} & \multicolumn{2}{|c|}{ Perde $\left.\left(\sum \mathrm{ti}\right)^{\wedge} 2\right) /\left(\sum \mathrm{Ni}\right)$} & \multicolumn{2}{|c|}{ Perde $\%$} \\
\hline E5 & 95.00 & E5 & 14.72 & E5 & 2.28 & E5 & 36.73 \\
\hline D5 & 62.00 & D5 & 7.85 & A4 & 1.14 & D5 & 19.59 \\
\hline F5 & 55.00 & F5 & 6.48 & D5 & 0.99 & F5 & 16.15 \\
\hline C5 & 35.00 & A4 & 4.89 & F5 & 0.76 & A4 & 12.21 \\
\hline G5 & 21.00 & $\mathrm{C} 5$ & 2.74 & G5 & 0.34 & $\mathrm{C} 5$ & 6.84 \\
\hline A4 & 21.00 & G5 & 2.67 & $\mathrm{C} 5$ & 0.21 & G5 & 6.65 \\
\hline A\#4 & 8.00 & A\#4 & 0.74 & A\#4 & 0.07 & A\#4 & 1.84 \\
\hline
\end{tabular}

Görsel 2. Ali gavak biçiyor isimli eserin MIDI analiz raporu (Yılmaz, 2021).

Dizisi: Eserin dizisi 7 perdeden ibaret olup yerinde Kürdî (BTTT) beşlisine Hüseynî perdesinde Kürdî (BT) üçlüsü eklenmiştir.

Etkinlik derecesi yüksek perdeler: Eserde Hüseynî perdesi, hem kullanım sıklığ1 ve süresi hem de toplam süreye oranı bakımından etkinlik derecesi en yüksek perdedir. Neva, Acem ve Dügâh perdeleri, kullanım oranları ve etkinlik dereceleri bakımından diğer önemli perdelerdir. Analiz raporunda görüleceği üzere eserin seyir yoğunluğu da dizinin birinci derecesi ile altıncı derecesi arasındadır.

Güçlüsü: Hüseynî 
Seyir karakteri: İnici-çıkıcı

Genişlemesi: Eserde dizi genişletilmemiştir.

Kalışlar: Dügâh perdesinde Kürdîli (4., 6., 10., 12. ve 16. ölçülerde),

Neva perdesinde Bûselikli (3., 5., 7., 9., 11., 13. ve 15. ölçülerde),

Hüseynî perdesinde Kürdîli (2., 8. ve 14. ölçülerde) kalışlar yapıllmıştır.

\section{Ayrıldım güler miyim isimli esere ait bulgular}

\begin{tabular}{|c|c|c|c|c|c|c|c|}
\hline \multicolumn{2}{|c|}{ Perde $\sum \mathrm{Ni}$} & \multicolumn{2}{|c|}{ Perde $\Sigma$ ti } & \multicolumn{2}{|c|}{ Perde $\left.\left(\sum \text { ti }\right)^{\wedge} 2\right) /\left(\sum \mathrm{Ni}\right)$} & \multicolumn{2}{|c|}{ Perde \% } \\
\hline F5 & 75.00 & C5 & 10.24 & C5 & 1.61 & C5 & 17.27 \\
\hline C5 & 65.00 & A4 & 9.65 & A4 & 1.55 & A4 & 16.27 \\
\hline A4 & 60.00 & F5 & 8.26 & D5 & 1.36 & F5 & 13.94 \\
\hline A\#4 & 58.00 & D5 & 7.55 & A5 & 1.34 & D5 & 12.73 \\
\hline E5 & 51.00 & A5 & 6.54 & F5 & 0.91 & A5 & 11.03 \\
\hline D5 & 42.00 & A\#4 & 5.27 & G5 & 0.79 & A\#4 & 8.88 \\
\hline A5 & 32.00 & E5 & 4.96 & E5 & 0.48 & E5 & 8.36 \\
\hline G5 & 27.00 & G5 & 4.62 & A\#4 & 0.48 & G5 & 7.78 \\
\hline G4 & 10.00 & F4 & 1.20 & F4 & 0.18 & F4 & 2.02 \\
\hline $\mathrm{F} 4$ & 8.00 & G4 & 0.97 & G4 & 0.09 & G4 & 1.63 \\
\hline A\#5 & 1.00 & A\#5 & 0.04 & A\#5 & 0.00 & A\#5 & 0.08 \\
\hline
\end{tabular}

Görsel 3. Ayrıldım güler miyim isimli eserin MIDI analiz raporu (Yılmaz, 2021).

Dizisi: Eserin dizisi yerinde Kürdî (BTTT) beşlisine Hüseynî perdesinde Kürdî (BTT) dörtlüsünün eklenmesiyle oluşmuştur.

Etkinlik derecesi yüksek perdeler: Eserde Çargâh perdesi, kullanım süresi ve toplam süreye oranı ve etkinlik derecesi bakımından ilk sırada yer almaktadır. Dügâh, Acem, Neva ve Muhayyer perdeleri, kullanım oranları ve etkinlik dereceleri bakımından diğer önemli perdelerdir. Analiz raporunda görüleceği üzere eserin seyri dizinin geneline yayılmakla beraber \%71,19 oranında ezgiler Çargâh perdesi ve üzerindeki perdelerde yoğunlaşmıştır.

Güçlüsü: Hüseynî

Seyir karakteri: İnici-çıkıc1 
Genişlemesi: Eserde dizi, pest taraftan Acem Aşirân perdesinde Çargâh (TT) üçlüsüyle genişletilirken tiz tarafta yalnızca Sümbüle perdesine kadar genişleme olmuştur.

Kalışlar: Dügâh perdesinde Kürdîli (2., 6., 12., 14., 15., 16. ve 18. ölçülerde),

Hüseynî perdesinde Kürdîli (8. ve 10. ölçülerde)

Acem Aşirân perdesinde Çargâhlı (1. ölçüde) kalışlar yapılmıştır.

\section{Bahçalarda barım var isimli esere ait bulgular}

\begin{tabular}{|c|c|c|c|c|c|c|c|}
\hline Perde & $\Sigma \mathrm{Ni}$ & Perde & $\sum \mathrm{ti}$ & Perd & $\left.\sum(\mathrm{ti})^{\wedge} 2\right) /\left(\sum \mathrm{Ni}\right)$ & Perd & $\%$ \\
\hline C5 & 148.00 & C5 & 20.87 & C5 & 2.94 & C5 & 23.98 \\
\hline A\#4 & 125.00 & D5 & 17.63 & D5 & 2.59 & D5 & 20.26 \\
\hline D5 & 120.00 & A\#4 & 16.26 & A4 & 2.56 & $\mathrm{~A} \# 4$ & 18.68 \\
\hline A4 & 97.00 & A4 & 15.76 & E5 & 2.19 & A4 & 18.11 \\
\hline E5 & 80.00 & E5 & 13.22 & A\#4 & 2.11 & E5 & 15.19 \\
\hline F5 & 8.00 & F5 & 1.54 & F5 & 0.30 & F5 & 1.77 \\
\hline G4 & 6.00 & A5 & 1.06 & A5 & 0.28 & A5 & 1.22 \\
\hline A5 & 4.00 & G4 & 0.69 & G4 & 0.08 & G4 & 0.79 \\
\hline
\end{tabular}

Görsel 4. Bahçalarda barım var isimli eserin MIDI analiz raporu (Yılmaz, 2021).

Dizisi: Eserin dizisi yerinde Kürdî (BTTT) beşlisine Hüseynî perdesinde Kürdî (BTT) dörtlüsünün eklenmesiyle oluşmuştur.

Etkinlik derecesi yüksek perdeler: MIDI raporunda Çargâh perdesi, tüm sütunlarda ilk s1rada yer almasına rağmen eserdeki kalışlarda çok önemli rol oynamamaktadır. Bu perdede iki yerde kalış yapılmakla birlikte bu kalışlar eserin başlangıç ve karara gidişteki kalışlarından değiller. Neva, Kürdî, Dügâh ve Hüseynî perdeleri, kullanım oranlanı ve etkinlik dereceleri bakımından diğer önemli perdelerdir. Analiz raporunda net bir şekilde görüleceği üzere eserin seyri \%96,22 gibi çok büyük bir oranla dizinin ilk beş perdesi arasında yoğunlaşmıştır.

Güçlüsü: Hüseynî perdesi MIDI raporunda toplam süreye oranla beşinci sırada yer almasına karşın eserin söz bölümündeki ilk kalış Hüseynî perdesinde yapılmış ve karara giden ezgilerde de sıklıkla yine bu perdeden hareket başlamış. Bu verileri dikkate alarak eserde Hüseynî perdesinin, çok baskın olmamakla birlikte, güçlü perde konumunda olduğunu söyleyebiliriz. 
Seyir karakteri: İnici-çıkıc1

Genişlemesi: Eserde dizi, yeden dışında genişlememiştir.

Kalışlar: Dügâh perdesinde Kürdîli (2., 7., 9., 11., 13., 15. ve 20. ölçülerde),

Kürdî perdesinde $\mathrm{TTT}^{2}$ li (5. ve 18. ölçülerde),

Çargâh perdesinde Çargâhlı (4., 17. ölçülerde),

Neva perdesinde Bûselikli (3. ve 16. ölçülerde),

Hüseynî perdesinde çeşnisiz (10. ölçüde) kalışlar yapılmıştır.

\section{Bu dă̆larda bă̆ olmaz isimli esere ait bulgular}

\begin{tabular}{|c|c|c|c|c|c|c|c|}
\hline Perde & $\sum \mathrm{Ni}$ & Perd & $\sum \mathrm{ti}$ & Perd & $\left.\left(\sum \mathrm{ti}\right)^{\wedge} 2\right) /\left(\sum \mathrm{Ni}\right)$ & Perd & $\%$ \\
\hline A4 & 78.00 & A4 & 19.81 & A4 & 5.03 & A4 & 36.29 \\
\hline E5 & 42.00 & D5 & 9.49 & D5 & 2.25 & D5 & 17.39 \\
\hline D5 & 40.00 & E5 & 7.83 & C5 & 1.47 & E5 & 14.35 \\
\hline C5 & 40.00 & $\mathrm{C} 5$ & 7.68 & E5 & 1.46 & C5 & 14.06 \\
\hline A\#4 & 38.00 & A\#4 & 6.09 & A\#4 & 0.98 & A\#4 & 11.16 \\
\hline F5 & 16.00 & F5 & 2.02 & G4 & 0.34 & F5 & 3.71 \\
\hline G4 & 8.00 & G4 & 1.66 & F5 & 0.26 & G4 & 3.04 \\
\hline
\end{tabular}

Görsel 5. Bu dağlarda bağ olmaz isimli eserin MIDI analiz raporu (Yılmaz, 2021).

Dizisi: Eserde karar perdesi üzerinde altı perde yer almakta olup dizi Kürdî altılısından ibarettir.

Etkinlik derecesi yüksek perdeler: Eserde Hüseynî perdesi, hem kullanım sıklığı ve süresi hem de toplam süreye oranı bakımından etkinlik derecesi en yüksek perdedir. Neva, Acem ve Dügâh perdeleri, kullanım oranları ve etkinlik dereceleri bakımından diğer önemli perdelerdir. Analiz raporunda görüleceği üzere eserin seyir yoğunluğu da dizinin birinci derecesi ile altıncı derecesi arasındadır.

2 Bu çeşninin ismine yazılı kaynaklarda rastlanılmamakla birlikte, sadece son aralıktaki bir komalık fark dışında Pençgâh beşlisi ile aynıdır. Geleneksel Türk halk müziğinde kullanılan 17 perdeli ses sistemi dikkate alındığında Çargâh perdesi üzerindeki Pençgâh çeşnisi ile Kürdî perdesi üzerinde inşa edilen bu çeşninin aralık oranları bakımından duyumu aynıdır. 
Güçlüsü: Neva

Seyir karakteri: Çıkıcı

Genişlemesi: Eserde dizi, yeden dışında genişlememiştir.

Kalışlar: Dügâh perdesinde Kürdîli (2., 4., 7., 9. ve 12. ölçülerde),

Neva perdesinde Bûselikli (5. ve 10. ölçülerde),

Hüseynî perdesinde çeşnisiz (1. ölçüde) kalışlar yapılmıştır.

\section{5. Çamlar altına isimli esere ait bulgular}

\begin{tabular}{|c|c|c|c|c|c|c|c|}
\hline \multicolumn{2}{|c|}{ Perde $\sum \mathrm{Ni}$} & \multicolumn{2}{|c|}{ Perde $\sum$ ti } & \multicolumn{2}{|c|}{ Perde $\left.\left(\sum \mathrm{ti}\right)^{\wedge} 2\right) /\left(\sum \mathrm{Ni}\right)$} & \multicolumn{2}{|c|}{ Perde $\%$} \\
\hline C5 & 75.00 & A4 & 15.42 & A4 & 3.83 & A4 & 36.60 \\
\hline A4 & 62.00 & $\mathrm{C} 5$ & 8.26 & C5 & 0.91 & C5 & 19.62 \\
\hline D5 & 57.00 & D5 & 5.96 & E5 & 0.87 & D5 & 14.15 \\
\hline E5 & 39.00 & E5 & 5.83 & D5 & 0.62 & E5 & 13.85 \\
\hline A\#4 & 36.00 & A\#4 & 2.90 & G4 & 0.31 & A\#4 & 6.90 \\
\hline F5 & 18.00 & G4 & 1.93 & $A \# 4$ & 0.23 & G4 & 4.59 \\
\hline G4 & 12.00 & F5 & 1.81 & F5 & 0.18 & F5 & 4.29 \\
\hline
\end{tabular}

Görsel 6. Çamlar altına isimli eserin MIDI analiz raporu (Yılmaz, 2021).

Dizisi: Eserde karar perdesi üzerinde altı perde yer almakta olup dizi Kürdî altılısından ibarettir.

Etkinlik derecesi yüksek perdeler: Eserde Dügâh perdesi, hem kullanım sıklı̆̆ı ve süresi hem de toplam süreye oranı bakımından etkinlik derecesi en yüksek perdedir. Çargâh, Neva ve Hüseynî perdeleri, kullanım oranları ve etkinlik dereceleri bakımından diğer önemli perdelerdir. Hüseynî perdesi toplam süreye oranda dördüncü sırada yer almasına karşın eserde karar perdesi dışında kalış yapılan tek perde ve ilk önemli kalışın yapıldığg1 perdedir. Karar perdesi üzerinde 6 perdeden oluşan eserin seyir yoğunluğu \%91,12 oranla karar ve güçlü perdeleri arasındadır.

Güçlüsü: Hüseynî

Seyir karakteri: İnici-çıkıcı 
Genişlemesi: Eserde dizi, yeden dişında genişlememiştir.

Kalışlar: Dügâh perdesinde Kürdîli (4., 12., 16., 24., 28. ve 36. ölçülerde),

Hüseynî perdesinde çeşnisiz (8., 20. ve 32. ölçülerde) kalışlar yapılmıştır.

\section{6. Çek gemici gemileri isimli esere ait bulgular}

\begin{tabular}{|c|c|c|c|c|c|c|c|}
\hline Perde & $\sum \mathrm{Ni}$ & Perd & $\Sigma \mathrm{ti}$ & Perc & $\left.\left(\sum \mathrm{ti}\right)^{\wedge} 2\right) /\left(\sum \mathrm{Ni}\right)$ & Perd & $\%$ \\
\hline D5 & 23.00 & A4 & 9.22 & A4 & 5.00 & A4 & 36.86 \\
\hline E5 & 20.00 & E5 & 5.10 & E5 & 1.30 & E5 & 20.38 \\
\hline A4 & 17.00 & D5 & 3.79 & F5 & 0.69 & D5 & 15.15 \\
\hline C5 & 17.00 & $\mathrm{C} 5$ & 2.95 & D5 & 0.62 & C5 & 11.78 \\
\hline F5 & 9.00 & F5 & 2.50 & $\mathrm{~A} \# 4$ & 0.53 & F5 & 9.98 \\
\hline A\#4 & 4.00 & A\#4 & 1.46 & C5 & 0.51 & A\#4 & 5.84 \\
\hline
\end{tabular}

Görsel 7. Çek gemici gemileri isimli eserin MIDI analiz raporu (Yılmaz, 2021).

Dizisi: Eserde karar perdesi üzerinde altı perde yer almakta olup dizi Kürdî altılısından ibarettir.

Etkinlik derecesi yüksek perdeler: Eserde karar perdesi, Dügâh, toplam süreye oranı bakımından etkinlik derecesi en yüksek perdedir. Hüseynî, Neva, Çargâh ve Acem perdeleri, kullanım oranları ve etkinlik dereceleri bakımından diğer önemli perdelerdir. Hüseynî perdesi, eserde karar perdesi dışında kalış yapılan tek perdedir. Karar perdesi üzerinde 6 perdeden oluşan eserin seyir yoğunluğu \%90,02 oranla karar ve güçlü perdeleri arasındadir.

Güçlüsü: Hüseynî

Seyir karakteri: İnici-çıkıcı

Genişlemesi: Eserde dizi genişletilmemiştir.

Kalışlar: Dügâh perdesinde Kürdîli (4., 9. ve 14. ölçülerde),

Hüseynî perdesinde çeşnisiz (11. ve 13. ölçülerde) kalışlar yapılmıştır. 


\section{7. Çekmecemin anahtarı kemikten isimli esere ait bulgular}

\begin{tabular}{|c|c|c|c|c|c|c|c|}
\hline \multicolumn{2}{|c|}{ Perde $\sum \mathrm{Ni}$} & \multicolumn{2}{|c|}{ Perde $\sum \mathrm{ti}$} & \multicolumn{2}{|c|}{ Perde $\left.\left(\sum \mathrm{ti}\right)^{\wedge} 2\right) /\left(\sum \mathrm{Ni}\right)$} & \multicolumn{2}{|c|}{ Perde $\%$} \\
\hline A4 & 72.00 & A4 & 25.73 & A4 & 9.20 & A4 & 41.61 \\
\hline D5 & 64.00 & $\mathrm{C} 5$ & 12.79 & C5 & 2.60 & C5 & 20.69 \\
\hline C5 & 63.00 & E5 & 10.81 & E5 & 1.95 & E5 & 17.48 \\
\hline E5 & 60.00 & D5 & 8.12 & D5 & 1.03 & D5 & 13.14 \\
\hline A\#4 & 25.00 & $\mathrm{A \# 4}$ & 3.59 & A\#4 & 0.51 & $\mathrm{A \# 4}$ & 5.80 \\
\hline F5 & 6.00 & F5 & 0.63 & F5 & 0.07 & F5 & 1.03 \\
\hline B4 & 2.00 & B4 & 0.15 & B4 & 0.01 & B4 & 0.25 \\
\hline
\end{tabular}

Görsel 8. Çekmecemin anahtarı kemikten isimli eserin MIDI analiz raporu (Yılmaz, 2021).

Dizisi: Eserde karar perdesi üzerinde 6 perde yer almakta olup yerinde Kürdî (BTTT) beşlisine Çargâh perdesinde Çargâh (TTB) dörtlüsünün eklendiği görülmektedir.

Etkinlik derecesi yüksek perdeler: Karar perdesi, Dügâh, tüm sütunlarda başta yer almakta ve eserde oldukça baskın bir şekilde kullanılmaktadır. MIDI analiz raporunda ikinci sırada yer alan Çargâh perdesi ise eserde cümle sonlarında önemli kalışların yapıldığı perdedir. Kullanım oranı ve etkinlik derecesi bakımından bu perdeleri Hüseynî, Neva ve Kürdî perdeleri takip etmektedir. Karar perdesi üzerinde 6 perdeden oluşan eserin seyir yoğunluğu \%90,97 oranla Dügâh ve Hüseynî perdeleri arasındadır.

Güçlüsü: Çargâh

Seyir karakteri: İnici-çıkıcı

Genişlemesi: Eserde dizi genişletilmemiştir.

Kalışlar: Dügâh perdesinde Kürdîli (2., 4., 7., 12., 14., 17., 22. ve 24. ölçülerde),

Çargâh perdesinde Çargâhlı (9. ve 19. ölçülerde),

Hüseynî perdesinde çeşnisiz (3., 13. ve 23. ölçülerde) kalışlar yapılmıştır. 


\section{8. Çıksam a Urumelinin düzüne isimli esere ait bulgular}

\begin{tabular}{|c|c|c|c|c|c|c|c|}
\hline Perde & $\sum \mathrm{Ni}$ & Perd & $\sum \mathrm{ti}$ & Perd & $\left.\sum(\mathrm{ti})^{\wedge} 2\right) /\left(\sum \mathrm{Ni}\right)$ & Perd & $\%$ \\
\hline D5 & 194.00 & D5 & 29.24 & D5 & 4.41 & D5 & 25.82 \\
\hline C5 & 144.00 & A4 & 21.29 & A4 & 4.20 & A4 & 18.80 \\
\hline A\#4 & 138.00 & C5 & 19.91 & C5 & 2.75 & C5 & 17.59 \\
\hline A4 & 108.00 & A\#4 & 18.65 & A\#4 & 2.52 & A\#4 & 16.47 \\
\hline E5 & 97.00 & E5 & 13.21 & E5 & 1.80 & E5 & 11.67 \\
\hline B4 & 36.00 & F5 & 4.97 & F5 & 1.03 & F5 & 4.39 \\
\hline F5 & 24.00 & B4 & 4.23 & B4 & 0.50 & B4 & 3.74 \\
\hline C\#5 & 15.00 & $\mathrm{C \# 5}$ & 1.73 & $\mathrm{C \# 5}$ & 0.20 & $\mathrm{C \# 5}$ & 1.52 \\
\hline
\end{tabular}

Görsel 9. Çıksam a Urumelinin düzüne isimli eserin MIDI analiz raporu (Yılmaz, 2021).

Dizisi: Eserde karar perdesi üzerinde altı perde yer almakta olup dizi Kürdî altılısından ibarettir.

Etkinlik derecesi yüksek perdeler: Eserde Neva perdesi, hem kullanım sıklığı ve süresi hem de toplam süreye oranı bakımından etkinlik derecesi en yüksek perdedir. Dügâh, Çargâh, Kürdî ve Hüseynî perdeleri, kullanım oranları ve etkinlik dereceleri bakımından diğer önemli perdelerdir. Karar perdesi üzerinde 6 perdeden oluşan eserin seyir yoğunluğu \%95,61 oranla Dügâh ve Hüseynî perdeleri arasındadır.

Güçlüsü: Eserde karar perdesi dışındaki hiçbir perdede kalış yapılmamıştır. Dolayısıyla güçlü perdeyi belirleyen en önemli unsur devre dışı kalmıştır. Bu durumda eseri karara getiren müzik cümlesine bakıldığında Neva perdesinden başlayan bir hareketin olduğu tespit edilmiştir. Ayrıca MIDI analiz raporunda Neva perdesinin etkinlik derecesi en yüksek perde olması da güçlü perdenin belirlenmesine yardımcı olmuştur.

Seyir karakteri: İnici-çıkıcı

Genişlemesi: Eserde dizi genişletilmemiştir.

Kalışlar: Dügâh perdesinde Kürdîli (4., 9., 14. ve 18. ölçülerde) kalışlar yapılmıştır. 


\section{Edremit'in gelini isimli esere ait bulgular}

\begin{tabular}{|c|c|c|c|c|c|c|c|}
\hline Perde & $\sum \mathrm{Ni}$ & Perd & $\sum \mathrm{ti}$ & Perd & $\left.(\Sigma \mathrm{ti})^{\wedge} 2\right) /(\Sigma \mathrm{Ni})$ & Perde & $\%$ \\
\hline E5 & 97.00 & E5 & 15.36 & E5 & 2.43 & E5 & 23.87 \\
\hline D5 & 67.00 & A4 & 11.54 & A4 & 2.38 & A4 & 17.94 \\
\hline F5 & 63.00 & D5 & 9.59 & G4 & 1.51 & D5 & 14.90 \\
\hline A4 & 56.00 & A5 & 5.78 & D5 & 1.37 & A5 & 8.98 \\
\hline G5 & 41.00 & A\#4 & 5.68 & A\#4 & 0.92 & A\#4 & 8.83 \\
\hline A5 & 41.00 & F5 & 5.38 & C5 & 0.88 & F5 & 8.36 \\
\hline A\#4 & 35.00 & C5 & 4.96 & A5 & 0.81 & C5 & 7.70 \\
\hline C5 & 28.00 & G4 & 3.25 & F5 & 0.46 & G4 & 5.05 \\
\hline G4 & 7.00 & G5 & 2.81 & G5 & 0.19 & G5 & 4.37 \\
\hline
\end{tabular}

Görsel 10. Edremit’in gelini isimli eserin MIDI analiz raporu (Yılmaz, 2021).

Dizisi: Eserin dizisi yerinde Kürdî (BTTT) beşlisine Hüseynî perdesinde Kürdî (BTT) dörtlüsünün eklenmesiyle oluşmuştur.

Etkinlik derecesi yüksek perdeler: Eserde Hüseynî perdesi, hem kullanım sıklığı ve süresi hem de toplam süreye oranı bakımından etkinlik derecesi en yüksek perdedir. Dügâh ve Neva perdeleri, kullanım oranları ve etkinlik dereceleri bakımından diğer önemli perdelerdir. Analiz raporunda görüleceği üzere dizinin tamamının kullanıldığı eserde seyir yoğunluğu \%73,24 oranla Dügâh ve Hüseynî perdeleri arasındadır.

Güçlüsü: Hüseynî

Seyir karakteri: İnici-çıkıcı

Genişlemesi: Eserde dizi, yeden dışında genişletilmemiştir.

Kalışlar: Dügâh perdesinde Kürdîli (4., 11. ve 18. ölçülerde),

Hüseynî perdesinde Kürdîli (6-7. ve 13.-14. ölçülerde),

Rast perdesinde Bûselikli (3., 10. ve 17. ölçülerde) kalışlar yapılmıştır. 


\section{Eklemedir koca konak isimli esere ait bulgular}

\begin{tabular}{|c|c|c|c|c|c|c|c|}
\hline Perde & $\sum \mathrm{Ni}$ & Perde & $\Sigma \mathrm{ti}$ & Perc & $\left.(\Sigma \mathrm{ti})^{\wedge} 2\right) /\left(\sum \mathrm{Ni}\right)$ & Perd & $\%$ \\
\hline A4 & 32.00 & A4 & 13.94 & A4 & 6.08 & A4 & 33.45 \\
\hline E5 & 28.00 & E5 & 6.87 & E5 & 1.69 & E5 & 16.48 \\
\hline D5 & 22.00 & A\#4 & 4.89 & $\mathrm{~A} \# 4$ & 1.41 & $\mathrm{~A} \# 4$ & 11.73 \\
\hline C5 & 18.00 & C5 & 4.85 & C5 & 1.31 & C5 & 11.64 \\
\hline A\#4 & 17.00 & D5 & 4.47 & D5 & 0.91 & D5 & 10.73 \\
\hline F5 & 8.00 & F5 & 1.83 & G5 & 0.54 & F5 & 4.39 \\
\hline G4 & 8.00 & G5 & 1.80 & F5 & 0.42 & G5 & 4.32 \\
\hline G5 & 6.00 & G4 & 1.77 & G4 & 0.39 & G4 & 4.25 \\
\hline $\mathrm{F} \# 5$ & 6.00 & F\#5 & 0.82 & $\mathrm{~F} \# 5$ & 0.11 & $\mathrm{~F} \# 5$ & 1.97 \\
\hline A5 & 2.00 & A5 & 0.43 & A5 & 0.09 & A5 & 1.04 \\
\hline
\end{tabular}

Görsel 11. Eklemedir koca konak isimli eserin MIDI analiz raporu (Yılmaz, 2021).

Dizisi: Eserin dizisi yerinde Kürdî (BTTT) beşlisine Çargâh perdesinde Pençgâh (TTKS) beşlisinin eklenmesiyle oluşmuştur.

Etkinlik derecesi yüksek perdeler: Eserde Dügâh perdesi, hem kullanım sıklığı ve süresi hem de toplam süreye oranı bakımından etkinlik derecesi en yüksek perdedir. Hüseynî, Kürdî, Çargâh ve Neva perdeleri, kullanım oranları ve etkinlik dereceleri bakımından diğer önemli perdelerdir. Analiz raporunda görüleceği üzere dizinin tamamının kullanıldığı eserde seyir yoğunluğu \%84,03 oranla Dügâh ve Hüseynî perdeleri arasındadır.

Güçlüsü: Eserde karar perdesi dışında yalnızca Çargâh perdesinde kalış yapılmıştır ve ilk yarım karar da yine bu perdede yapılmıştır. MIDI analiz raporunda Çargâh perdesi her ne kadar dördüncü sırada kalsa da eserde anlamlı bir kalışın olduğu karar perdesi dışındaki tek perdedir. Dolayısıyla klasik Türk müziği Kürdî makamı eserlerinde nadiren de olsa karşılaşılan (Yılmaz 2019, 115) Çargâh perdesinin güçlü perde olma durumu bu eser için de söz konusudur. Bu eserde dikkat çeken diğer bir nokta ise Çargâh perdesindeki kalışlarda Acem yerine Eviç perdesi kullanılarak, Çargâhlı değil de Pençgâhlı kalış yapılmış olmasıdır.

Seyir karakteri: Çıkıcı

Genişlemesi: Eserde dizi, yeden dışında genişletilmemiştir.

Kalışlar: Dügâh perdesinde Kürdîli (7.-8., 16. ve 20. ölçülerde),

Çargâh perdesinde Pençgâhlı (4. ve 12. ölçülerde) kalışlar yapılmıştır. 


\section{Elif dedim be dedim isimli esere ait bulgular}

\begin{tabular}{ll} 
Perde & $\sum \mathrm{Ni}$ \\
\hline E5 & 95.00 \\
D5 & 58.00 \\
F5 & 44.00 \\
A4 & 44.00 \\
C5 & 43.00 \\
G5 & 34.00 \\
A5 & 26.00 \\
A\#4 & 20.00 \\
A\#5 & 12.00 \\
G4 & 2.00 \\
B5 & 2.00
\end{tabular}

\begin{tabular}{ll} 
Perde & $\sum \mathrm{ti}$ \\
\hline E5 & 19.08 \\
A4 & 14.80 \\
D5 & 8.47 \\
C5 & 8.10 \\
A5 & 7.09 \\
F5 & 6.71 \\
G5 & 4.53 \\
A\#4 & 3.04 \\
A\#5 & 1.14 \\
G4 & 0.44 \\
B5 & 0.42
\end{tabular}

$\begin{array}{ll}\text { Perde } & \left.\left(\sum \mathrm{ti}\right)^{\wedge} 2\right) /\left(\sum \mathrm{Ni}\right) \\ \text { A4 } & 4.98 \\ \text { E5 } & 3.83 \\ \text { A5 } & 1.93 \\ \text { C5 } & 1.53 \\ \text { D5 } & 1.24 \\ \text { F5 } & 1.02 \\ \text { G5 } & 0.60 \\ \text { A\#4 } & 0.46 \\ \text { A\#5 } & 0.11 \\ \text { G4 } & 0.10 \\ \text { B5 } & 0.09\end{array}$

\begin{tabular}{ll} 
Perde & $\%$ \\
\hline E5 & 25.85 \\
A4 & 20.05 \\
D5 & 11.47 \\
C5 & 10.97 \\
A5 & 9.60 \\
F5 & 9.10 \\
G5 & 6.14 \\
A\#4 & 4.12 \\
A\#5 & 1.54 \\
G4 & 0.59 \\
B5 & 0.57
\end{tabular}

Görsel 12. Elif dedim be dedim isimli eserin MIDI analiz raporu (Yılmaz, 2021).

Dizisi: Eserin dizisi yerinde Kürdî (BTTT) beşlisine Hüseynî perdesinde Kürdî (BTT) dörtlüsünün eklenmesiyle oluşmuştur.

Etkinlik derecesi yüksek perdeler: Eserde Hüseynî perdesi, hem kullanım sıklığı ve süresi hem de toplam süreye oranı bakımından etkinlik derecesi en yüksek perdedir. Dügâh, Neva ve Çargâh perdeleri, kullanım oranları ve etkinlik dereceleri bakımından diğer önemli perdelerdir. Analiz raporunda görüleceği üzere dizinin tamamının kullanıldığı eserde seyir yoğunluğu \%72,46 oranla Dügâh ve Hüseynî perdeleri arasındadır.

Güçlüsü: Hüseynî

Seyir karakteri: İnici-çıkıcı

Genişlemesi: Eserde dizi, yeden ve tiz tarafta Sümbüle ve Tiz Bûselik perdeleri dışında genişletilmemiştir.

Kalışlar: Dügâh perdesinde Kürdîli (1., 2., 5, 6.-7., ve 11. ölçülerde),

Çargâh perdesinde Çargâhlı (10. ölçüde),

Hüseynî perdesinde Kürdîli (8. ölçüde) kalışlar yapıllmıştır. 


\section{Evlerinin önü yoldur isimli esere ait bulgular}

\begin{tabular}{|c|c|c|c|c|c|c|c|}
\hline Perde & $\sum \mathrm{Ni}$ & Perd & $\sum \mathrm{ti}$ & Perd & $\left.\left(\sum \mathrm{ti}\right)^{\wedge} 2\right) /\left(\sum \mathrm{Ni}\right)$ & Perd & $\%$ \\
\hline C5 & 78.00 & A4 & 18.84 & A4 & 5.38 & A4 & 27.35 \\
\hline A4 & 66.00 & C5 & 18.15 & C5 & 4.22 & C5 & 26.35 \\
\hline E5 & 54.00 & E5 & 10.35 & E5 & 1.99 & E5 & 15.03 \\
\hline D5 & 50.00 & D5 & 8.35 & D5 & 1.39 & D5 & 12.12 \\
\hline A\#4 & 38.00 & A\#4 & 5.84 & $\mathrm{A \# 4}$ & 0.90 & $A \# 4$ & 8.47 \\
\hline F5 & 28.00 & F5 & 4.35 & F5 & 0.67 & F5 & 6.31 \\
\hline G5 & 14.00 & G5 & 3.01 & G5 & 0.65 & G5 & 4.37 \\
\hline
\end{tabular}

Görsel 13. Evlerinin önü yoldur isimli eserin MIDI analiz raporu (Yılmaz, 2021).

Dizisi: Eserin dizisi 7 perdeden ibaret olup yerinde Kürdî (BTTT) beşlisine Çargâh perdesinde Çargâh (TTBT) beşlisi eklenmiştir.

Etkinlik derecesi yüksek perdeler: Eserde Dügâh perdesi, hem kullanım süresi hem de toplam süreye oranı bakımından etkinlik derecesi en yüksek perdedir. Çargâh perdesi de kullanım oranı bakımından karar perdesine yakın oranda kullanılmış ve eserde ilk yarım karar bu perdede yapılmıştır. Hüseynî ve Neva perdeleri, kullanım oranları ve etkinlik dereceleri bakımından diğer önemli perdelerdir. Analiz raporunda görüleceği üzere karar perdesi üzerinde 7 perdenin olduğu eserde seyir yoğunluğu \%89,32 oranla Dügâh ve Hüseynî perdeleri arasındadır.

Güçlüsü: Çargâh

Seyir karakteri: İnici-çıkıcı

Genişlemesi: Eserde dizi genişletilmemiştir.

Kalışlar: Dügâh perdesinde Kürdîli (2., 8. ve 14. ölçülerde),

Çargâh perdesinde Çargâhlı (5. ve 11. ölçülerde) kalışlar yapılmıştır. 


\section{Hacel obası isimli esere ait bulgular}

\begin{tabular}{|c|c|c|c|c|c|c|c|}
\hline Perde & $\sum \mathrm{Ni}$ & Perde & $\sum \mathrm{ti}$ & Perd & $\left.\sum(\mathrm{ti})^{\wedge} 2\right) /\left(\sum \mathrm{Ni}\right)$ & Perde & $\%$ \\
\hline E5 & 55.00 & $\mathrm{C} 5$ & 10.20 & C5 & 2.00 & C5 & 32.68 \\
\hline C5 & 52.00 & E5 & 6.17 & A4 & 0.71 & E5 & 19.77 \\
\hline D5 & 44.00 & D5 & 4.51 & E5 & 0.69 & D5 & 14.45 \\
\hline F5 & 32.00 & A4 & 4.13 & D5 & 0.46 & A4 & 13.23 \\
\hline A\#4 & 24.00 & F5 & 3.28 & F5 & 0.34 & F5 & 10.52 \\
\hline A4 & 24.00 & A\#4 & 1.91 & A\#4 & 0.15 & A\#4 & 6.11 \\
\hline G5 & 8.00 & G5 & 1.01 & G5 & 0.13 & G5 & 3.24 \\
\hline
\end{tabular}

Görsel 14. Hacel obası isimli eserin MIDI analiz raporu (Yılmaz, 2021).

Dizisi: Eserin dizisi 7 perdeden ibaret olup yerinde Kürdî (BTTT) beşlisine Hüseynî perdesinde Kürdî (BT) üçlüsü eklenmiştir.

Etkinlik derecesi yüksek perdeler: MIDI analiz raporunda Çargâh perdesi hem kullanım süresi hem de toplam süreye oranı bakımından etkinlik derecesi en yüksek perdedir. Kullanım sıklığı bakımından birinci sırada yer alan Hüseynî perdesi toplam süreye oranı bakımından da ikinci sırada yer almaktadır. Ayrıca ilk yarım kararlar da bu perde üzerinde yapılmıştır. Neva, Dügâh ve Acem perdeleri, kullanım oranları ve etkinlik dereceleri bakımından diğer önemli perdelerdir. Analiz raporunda görüleceği üzere karar perdesi üzerinde 7 perdenin olduğu eserde seyir yoğunluğu \%86,24 oranla Dügâh ve Hüseynî perdeleri arasındadir.

Güçlüsü: Hüseynî

Seyir karakteri: İnici-çıkıcı

Genişlemesi: Eserde dizi genişletilmemiştir.

Kalışlar: Dügâh perdesinde Kürdîli (4. ve 12. ölçülerde),

Çargâh perdesinde Çargâhlı (2., 8. ve 10. ölçülerde)

Hüseynî perdesinde Kürdîli (5. ve 6. ölçülerde) kalışlar yapılmıştır. 


\section{Karahisar kalesi isimli esere ait bulgular}

\begin{tabular}{|c|c|c|c|c|c|c|c|}
\hline Perde & $\sum \mathrm{Ni}$ & Perd & $\sum \mathrm{ti}$ & Perc & $\left.(\mathrm{ti})^{\wedge} 2\right) /(\Sigma \mathrm{Ni})$ & Perd & $\%$ \\
\hline G5 & 27.00 & A5 & 7.55 & A5 & 2.28 & A5 & 27.89 \\
\hline A5 & 25.00 & A4 & 5.22 & A4 & 2.27 & A4 & 19.29 \\
\hline D5 & 25.00 & D5 & 4.28 & D5 & 0.73 & D5 & 15.83 \\
\hline A4 & 12.00 & G5 & 4.02 & C5 & 0.72 & G5 & 14.87 \\
\hline F5 & 12.00 & C5 & 2.54 & G5 & 0.60 & $\mathrm{C} 5$ & 9.38 \\
\hline E5 & 12.00 & A\#4 & 1.20 & $\mathrm{A \# 4}$ & 0.18 & A\#4 & 4.45 \\
\hline C5 & 9.00 & F5 & 1.13 & F5 & 0.11 & F5 & 4.18 \\
\hline A\#4 & 8.00 & E5 & 1.11 & E5 & 0.10 & E5 & 4.10 \\
\hline
\end{tabular}

Görsel 15. Karahisar kalesi isimli eserin MIDI analiz raporu (Yılmaz, 2021).

Dizisi: Yerinde Kürdî (BTT) dörtlüsüne Neva perdesinde Bûselik (TBTT) beşlisi; ayrıca Çargâh perdesinde Çargâh (TTB) beşlisi eklenmiştir.

Etkinlik derecesi yüksek perdeler: Eserde tiz durak Muhayyer perdesi hem kullanım süresi hem de toplam süreye oranı bakımından etkinlik derecesi en yüksek perdedir. Onu Dügâh, Neva, Gerdaniye ve Çargâh perdeleri takip etmektedir. Genel Kürdî makamı seyrine ve incelenen türkülere aykırı olan bu eserde tiz durak ve civarındaki perdelerin kullanım oranları dikkat çekicidir.

Güçlüsü: Muhayyer

Seyir karakteri: İnici

Genişlemesi: Eserde dizi genişletilmemiştir.

Kalışlar: Dügâh perdesinde Kürdîli (8.-9., 16.-17. ve 21.-22. ölçülerde), Çargâh perdesinde Çargâhlı (7., 15. ve 20. ölçülerde),

Muhayyer perdesinde çeşnisiz (4. ölçüde) kalışlar yapılmıştır. 


\section{Kayayı gırcı tuttu isimli esere ait bulgular}

\begin{tabular}{|c|c|c|c|c|c|c|c|}
\hline Perde & $\Sigma \mathrm{Ni}$ & Perd & $\sum \mathrm{ti}$ & \multicolumn{2}{|c|}{ Perde $\left.\left(\sum \mathrm{ti}\right)^{\wedge} 2\right) /\left(\sum \mathrm{Ni}\right)$} & \multicolumn{2}{|c|}{ Perde $\%$} \\
\hline E5 & 78.00 & E5 & 12.15 & E5 & 1.89 & E5 & 35.90 \\
\hline C5 & 50.00 & C5 & 6.15 & C5 & 0.76 & C5 & 18.16 \\
\hline D5 & 42.00 & D5 & 5.20 & D5 & 0.64 & D5 & 15.36 \\
\hline A4 & 32.00 & A4 & 4.24 & A4 & 0.56 & A4 & 12.53 \\
\hline A\#4 & 30.00 & $\mathrm{A \# 4}$ & 3.44 & A\#4 & 0.39 & A\#4 & 10.17 \\
\hline F5 & 21.00 & F5 & 2.05 & F5 & 0.20 & F5 & 6.05 \\
\hline G5 & 4.00 & G5 & 0.43 & G5 & 0.05 & G5 & 1.28 \\
\hline G4 & 2.00 & G4 & 0.18 & G4 & 0.02 & G4 & 0.54 \\
\hline
\end{tabular}

Görsel 16. Kayayı gırcı tuttu isimli eserin MIDI analiz raporu (Yılmaz, 2021).

Dizisi: Eserin dizisi 7 perdeden ibaret olup yerinde Kürdî (BTTT) beşlisine Hüseynî perdesinde Kürdî (BT) üçlüsü eklenmiştir.

Etkinlik derecesi yüksek perdeler: MIDI analiz raporunda Hüseynî perdesi tüm sütunlarda önemli ölçüde farkla birinci sırada yer almaktadır. Çargâh, Neva, Dügâh ve Kürdî perdeleri, kullanım oranları ve etkinlik dereceleri bakımından diğer önemli perdelerdir. Analiz raporunda görüleceği üzere eserde seyir yoğunluğu \%92,13 oranla Dügâh ve Hüseynî perdeleri arasındadır.

Güçlüsü: Hüseynî

Seyir karakteri: İnici-çıkıcı

Genişlemesi: Eserde dizi genişletilmemiştir.

Kalışlar: Dügâh perdesinde Kürdîli (5., 10. ve 16. ölçülerde),

Çargâh perdesinde Çargâhlı (3., 8. ve 13. ölçülerde),

Hüseynî perdesinde çeşnisiz (1., 2., 6., 7., 11. ve 12. ölçülerde) kalışlar yapıllmıştır. 


\section{Kırmızı buğgay isimli esere ait bulgular}

\begin{tabular}{|c|c|c|c|c|c|c|c|}
\hline Perde & $\sum \mathrm{Ni}$ & Perde & $\sum \mathrm{ti}$ & Perd & $\left.\sum(\mathrm{ti})^{\wedge} 2\right) /\left(\sum \mathrm{Ni}\right)$ & Perd & $\%$ \\
\hline A4 & 48.00 & A4 & 11.95 & A4 & 2.98 & A4 & 34.65 \\
\hline E5 & 42.00 & E5 & 6.05 & E5 & 0.87 & E5 & 17.53 \\
\hline F5 & 38.00 & F5 & 3.80 & A5 & 0.63 & F5 & 11.01 \\
\hline A\#4 & 24.00 & A\#4 & 2.82 & F5 & 0.38 & A\#4 & 8.18 \\
\hline D5 & 22.00 & $\mathrm{C} 5$ & 2.65 & A\#4 & 0.33 & $\mathrm{C} 5$ & 7.69 \\
\hline C5 & 22.00 & A5 & 2.52 & $\mathrm{C} 5$ & 0.32 & A5 & 7.30 \\
\hline G5 & 18.00 & D5 & 2.24 & G5 & 0.24 & D5 & 6.50 \\
\hline A5 & 10.00 & G5 & 2.07 & D5 & 0.23 & G5 & 6.00 \\
\hline G4 & 4.00 & G4 & 0.39 & G4 & 0.04 & G4 & 1.14 \\
\hline
\end{tabular}

Görsel 17. Kırmızı buğday isimli eserin MIDI analiz raporu (Yılmaz, 2021).

Dizisi: Eserin dizisi yerinde Kürdî (BTTT) beşlisine Hüseynî perdesinde Kürdî (BTT) dörtlüsünün eklenmesiyle oluşmuştur.

Etkinlik derecesi yüksek perdeler: MIDI analiz raporunda Dügâh perdesi tüm sütunlarda birinci sırada yer almaktadır. İkinci sırada yer alan Hüseynî perdesi aynı zamanda eserde karar perdesi dışında kalış yapılan ve ilk yarım kararın yapıldığı perdedir. Toplam süreye oranı bakımından üçüncü sırada ise Acem perdesi yer almaktadır. Tüm makam dizisinin kullanıldığı eserde seyir yoğunluğu \%74,55 oranla Dügâh ve Hüseynî perdeleri arasında yoğunlaşmaktadır.

Güçlüsü: Hüseynî

Seyir karakteri: İnici-çıkıc1

Genişlemesi: Eserde dizi, yeden dışında genişletilmemiştir.

Kalışlar: Dügâh perdesinde Kürdîli (4., 6., 10., 12., 13. ve 15. ölçülerde),

Hüseynî perdesinde Kürdîli (2., ve 8. ölçülerde) kalışlar yapılmıştır. 


\section{Köprünün altı testi isimli esere ait bulgular}

\begin{tabular}{|c|c|c|c|c|c|c|c|}
\hline \multicolumn{2}{|c|}{ Perde $\Sigma \mathrm{Ni}$} & \multicolumn{2}{|c|}{ Perde $\Sigma \mathrm{ti}$} & \multicolumn{2}{|c|}{ Perde $\left.\left(\sum \mathrm{ti}\right)^{\wedge} 2\right) /\left(\sum \mathrm{Ni}\right)$} & \multicolumn{2}{|c|}{ Perde \% } \\
\hline A4 & 60.00 & A4 & 10.82 & A4 & 1.95 & A4 & 39.28 \\
\hline E5 & 28.00 & $\mathrm{C} 5$ & 5.07 & C5 & 0.95 & C5 & 18.38 \\
\hline C5 & 27.00 & E5 & 3.95 & E5 & 0.56 & E5 & 14.34 \\
\hline F5 & 20.00 & F5 & 2.83 & F5 & 0.40 & F5 & 10.28 \\
\hline D5 & 20.00 & D5 & 2.24 & D5 & 0.25 & D5 & 8.11 \\
\hline G4 & 11.00 & G4 & 1.05 & G4 & 0.10 & G4 & 3.80 \\
\hline A\#4 & 9.00 & $\mathrm{A \# 4}$ & 0.85 & $\mathrm{A \# 4}$ & 0.08 & A\#4 & 3.08 \\
\hline G5 & 8.00 & G5 & 0.75 & G5 & 0.07 & G5 & 2.73 \\
\hline
\end{tabular}

Görsel 18. Köprünün altı testi isimli eserin MIDI analiz raporu (Yılmaz, 2021).

Dizisi: Eserin dizisi 7 perdeden ibaret olup yerinde Kürdî (BTTT) beşlisine Hüseynî perdesinde Kürdî (BT) üçlüsü; ayrıca Çargâh perdesinde Çargâh (TTB) dörtlüsü eklenmiştir.

Etkinlik derecesi yüksek perdeler: Eserde Dügâh perdesi, hem kullanım sıklığı ve süresi hem de toplam süreye oranı bakımından etkinlik derecesi en yüksek perdedir. Güçlü perde konumunda olan Çargâh perdesi ise kullanım sıklığı dışındaki tüm sütunlarda ikinci sırada yer almaktadır. Hüseynî, Acem ve Neva perdeleri, kullanım oranları ve etkinlik dereceleri bakımından diğer önemli perdelerdir. Eserde seyir yoğunluğu \%83,19 oranla Dügâh ve Hüseynî perdeleri arasında yoğunlaşmaktadır.

Güçlüsü: Çargâh

Seyir karakteri: Çıkıcı

Genişlemesi: Eserde dizi, yeden dışında genişletilmemiştir.

Kalışlar: Dügâh perdesinde Kürdîli (1., 4., 5., 8., 10. ve 12. ölçülerde), Çargâh perdesinde Çargâhlı (3., 6., 7., 9. ve 11. ölçülerde), Hüseynî perdesinde Kürdîli (2. ölçüde) kalışlar yapılmıştır. 


\section{Kütahyanın pınarları isimli esere ait bulgular}

\begin{tabular}{|c|c|c|c|c|c|c|c|}
\hline Perde & $\sum \mathrm{Ni}$ & Perd & $\sum \mathrm{ti}$ & Perc & $\left.\left(\sum \mathrm{ti}\right)^{\wedge} 2\right) /\left(\sum \mathrm{Ni}\right)$ & Perde & $\%$ \\
\hline A4 & 85.00 & A4 & 20.34 & A4 & 4.87 & $\mathrm{~A} 4$ & 36.48 \\
\hline E5 & 62.00 & E5 & 13.08 & E5 & 2.76 & E5 & 23.47 \\
\hline A\#4 & 46.00 & C5 & 5.49 & C5 & 0.81 & C5 & 9.84 \\
\hline F5 & 38.00 & F5 & 5.32 & F5 & 0.74 & F5 & 9.54 \\
\hline C5 & 37.00 & A\#4 & 4.93 & D5 & 0.59 & A\#4 & 8.85 \\
\hline D5 & 28.00 & D5 & 4.06 & A\#4 & 0.53 & D5 & 7.28 \\
\hline G5 & 11.00 & G4 & 1.51 & G4 & 0.33 & G4 & 2.72 \\
\hline G4 & 7.00 & G5 & 1.01 & G5 & 0.09 & G5 & 1.82 \\
\hline
\end{tabular}

Görsel 19. Kütahyanın pınarlart isimli eserin MIDI analiz raporu (Yılmaz, 2021).

Dizisi: Eserin dizisi 7 perdeden ibaret olup yerinde Kürdî (BTTT) beşlisine Hüseynî perdesinde Kürdî (BT) üçlüsü eklenmiştir.

Etkinlik derecesi yüksek perdeler: Eserde Dügâh perdesi, hem kullanım sıklığı ve süresi hem de toplam süreye oranı bakımından etkinlik derecesi en yüksek perdedir. Güçlü perde konumunda olan Hüseynî perdesi ise tüm sütunlarda ikinci sırada yer almaktadır. Diğer perdeler bu iki perdenin oldukça altında bir oranda kullanılmıştır. Öyle ki karar perdesi ve güçlü Hüseynî perdesinin toplam kullanım oranı eserin toplam süresinin \%59,95'lik kısmını kapsamaktadır. Eserde seyir yoğunluğu \%85,92 oranla Dügâh ve Hüseynî perdeleri arasında yoğunlaşmaktadır.

Güçlüsü: Hüseynî

Seyir karakteri: İnici-çıkıcı

Genişlemesi: Eserde dizi genişletilmemiştir.

Kalışlar: Dügâh perdesinde Kürdîli (4., 6., 10., 12. ve 16. ölçülerde),

Neva perdesinde Bûselikli (3., 5., 7., 9., 11., 13. ve 15. ölçülerde)

Hüseynî perdesinde Kürdîli (2., 8. ve 14. ölçülerde) kalışlar yapılmıştır. 


\section{Sandık üstünde sandık isimli esere ait bulgular}

\begin{tabular}{llllllllll} 
Perde & $\sum \mathrm{Ni}$ & Perde & $\sum \mathrm{ti}$ & & \multicolumn{2}{l}{ Perde } & $\left.(\Sigma \mathrm{ti})^{\wedge} 2\right) /\left(\sum \mathrm{Ni}\right)$ & & \multicolumn{2}{l}{ Perde } & $\%$ \\
E5 & 19.00 & E5 & 2.33 & & A4 & 0.42 & & E5 & 23.89 \\
D5 & 13.00 & A4 & 2.16 & E5 & 0.29 & & A4 & 22.12 \\
F5 & 12.00 & C5 & 1.73 & C5 & 0.27 & & C5 & 17.76 \\
A4 & 11.00 & D5 & 1.37 & D5 & 0.15 & D5 & 14.09 \\
C5 & 11.00 & F5 & 0.94 & F5 & 0.07 & F5 & 9.68 \\
A\#4 & 4.00 & A\#4 & 0.39 & D\#5 & 0.04 & A\#4 & 3.96 \\
D\#5 & 3.00 & D\#5 & 0.36 & A\#4 & 0.04 & D\#5 & 3.69 \\
G4 & 3.00 & G4 & 0.28 & G4 & 0.03 & G4 & 2.89 \\
G5 & 2.00 & G5 & 0.19 & G5 & 0.02 & G5 & 1.91
\end{tabular}

Görsel 20. Sandık üstünde sandık isimli eserin MIDI analiz raporu (Yılmaz, 2021).

Dizisi: Eserin dizisi 7 perdeden ibaret olup yerinde Kürdî (BTTT) beşlisine Hüseynî perdesinde Kürdî (BT) üçlüsü eklenmiştir.

Etkinlik derecesi yüksek perdeler: Eserde Hüseynî perdesi, hem kullanım sıklığı ve süresi hem de toplam süreye oranı bakımından etkinlik derecesi en yüksek perdedir. Dügâh, Çargâh ve Neva perdeleri, kullanım oranları ve etkinlik dereceleri bakımından diğer önemli perdelerdir. Analiz raporunda görüleceği üzere karar perdesi üzerinde 7 perdenin olduğu eserde seyir yoğunluğu \%94,52 oranla Dügâh ve Hüseynî perdeleri arasindadir.

\section{Güçlüsü: Hüseynî}

Seyir karakteri: İnici-çıkıcı

Genişlemesi: Eserde dizi, yeden dışında genişletilmemiştir.

Kalışlar: Dügâh perdesinde Kürdîli (4., 6., 10., 12. ve 16. ölçülerde),

Neva perdesinde Bûselikli (3., 5., 7., 9., 11., 13. ve 15. ölçülerde)

Hüseynî perdesinde Kürdîli (2., 8. ve 14. ölçülerde) kalışlar yapılmıştır. 


\section{0. Şu Köyceğiz yoları isimli esere ait bulgular}

\begin{tabular}{|c|c|c|c|c|c|c|c|}
\hline \multicolumn{2}{|c|}{ Perde $\sum \mathrm{Ni}$} & \multicolumn{2}{|c|}{ Perde $\Sigma \mathrm{ti}$} & \multicolumn{2}{|c|}{ Perde $\left.\left(\sum \mathrm{ti}\right)^{\wedge} 2\right) /\left(\sum \mathrm{Ni}\right)$} & \multicolumn{2}{|c|}{ Perde $\%$} \\
\hline $\mathrm{A} 4$ & 59.00 & $\mathrm{~A} 4$ & 18.41 & A4 & 5.75 & A4 & 44.03 \\
\hline A\#4 & 49.00 & C5 & 7.58 & C5 & 1.25 & C5 & 18.13 \\
\hline C5 & 46.00 & $\mathrm{A \# 4}$ & 6.42 & E5 & 1.11 & A\#4 & 15.34 \\
\hline E5 & 20.00 & E5 & 4.71 & A\#4 & 0.84 & E5 & 11.25 \\
\hline D5 & 19.00 & D5 & 2.73 & D5 & 0.39 & D5 & 6.53 \\
\hline F5 & 10.00 & D\#5 & 1.04 & D\#5 & 0.15 & D\#5 & 2.48 \\
\hline D\#5 & 7.00 & F5 & 0.93 & F5 & 0.09 & F5 & 2.24 \\
\hline
\end{tabular}

Görsel 21. Şu Köyceğiz yolart isimli eserin MIDI analiz raporu (Yılmaz, 2021).

Dizisi: Eserde karar perdesi üzerinde altı perde yer almakta olup dizi Kürdî altılısından ibarettir.

Etkinlik derecesi yüksek perdeler: Eserde Dügâh perdesi, hem kullanım sıklığı ve süresi hem de toplam süreye oranı bakımından etkinlik derecesi en yüksek perdedir. Çargâh, Kürdî ve Hüseynî perdeleri, kullanım oranları ve etkinlik dereceleri bakımından diğer önemli perdelerdir. Hüseynî perdesi, toplam süreye oranı bakımından dördüncü sırada yer almasına karşın eserde karar perdesi dışında kalış yapılan ve üzerinde ilk yarım kararın yapıldığı perdedir. Karar perdesi üzerinde 6 perdenin olduğu eserde seyir yoğunluğu \%97,76 oranla Dügâh ve Hüseynî perdeleri arasındadır.

Güçlüsü: Hüseynî

Seyir karakteri: İnici-çıkıc1

Genişlemesi: Eserde dizi genişletilmemiştir.

Kalışlar: Dügâh perdesinde Kürdîli (1., 3., 7., 9.-10., 11., 13, 14. ve 15.-16. ölçülerde), Hüseynî perdesinde çeşnisiz (5. ölçüde) kalışlar yapılmıştır. 


\section{Sonuç ve Öneriler}

Araştırma bulgularından hareketle şu sonuçlara ulaşılmıştır:

Tablo 2. İncelenen tüm eserlerin ortak MIDI analizi (Y1lmaz, 2021)

\begin{tabular}{|c|c|c|c|c|}
\hline & $\begin{array}{c}\text { Kullanım Sıklığı } \\
\sum \mathbf{N}\end{array}$ & $\begin{array}{c}\text { Kullanım Süresi } \\
\sum \mathbf{t}\end{array}$ & $\begin{array}{c}\text { Etkinlik Derecesi } \sum \mathbf{t}^{2} \\
/ \sum \mathbf{N}\end{array}$ & $\begin{array}{c}\text { Toplam Süreye } \\
\text { Oranı \% }\end{array}$ \\
\hline 1 & E5 1221 & A4 363,12 & A4 108,34 & A4 25,48 \\
\hline 2 & A4 1217 & E5 238,51 & C5 47,09 & E5 18,22 \\
\hline 3 & C5 1127 & C5 230,38 & E5 46,59 & C5 16,48 \\
\hline 4 & D5 1120 & D5 213,23 & D5 40,59 & D5 14,83 \\
\hline 5 & A\#4 814 & A\#4 142,59 & A\#4 24,98 & A\#4 9,85 \\
\hline 6 & F5 617 & F5 87,46 & F5 12,40 & F5 6,84 \\
\hline 7 & G5 240 & A5 32,22 & A5 7,31 & A5 3,03 \\
\hline 8 & A5 142 & G5 30,78 & G5 3,94 & G5 2,68 \\
\hline 9 & G4 95 & G4 18,68 & G4 3,67 & G4 1,29 \\
\hline 10 & B4 40 & B4 8,53 & B4 1,82 & B4 0,56 \\
\hline 11 & C\#5 15 & C\#5 3,24 & $\mathrm{C} \# 50,70$ & $\mathrm{C} \# 5$ 0,21 \\
\hline 12 & $\mathrm{D} \# 5 \quad 13$ & $\mathrm{D \# 5} 1,76$ & $\mathrm{D} \# 5 \quad 0,24$ & D\#5 0,14 \\
\hline 13 & $\mathrm{~A} \# 513$ & A\#5 1,24 & F4 0,18 & $\mathrm{~A} \# 50,12$ \\
\hline 14 & F4 8 & F4 1,20 & F\#5 0,13 & F4 0,07 \\
\hline 15 & F\#5 5 & F\#5 0,82 & A\#5 0,11 & F\#5 0,06 \\
\hline 16 & B5 2 & B5 0,42 & B5 0,09 & B5 0,05 \\
\hline
\end{tabular}

İncelenen 20 türkünün ortak MIDI analizi sonuçlarını gösteren Tablo 2 incelendiğinde; karar perdesi Dügâhın toplam süre, etkinlik derecesi ve kullanım oranı bakımlarından en etkili perde olduğu görülmektedir. Hüseynî perdesi ise kullanım sıklığında birinci sırada yer alırken kullanım süresi ve toplam süreye oranda ikinci sırada yer almaktadır. Kalışlarda da bu perdenin ne derece önemli olduğu görülmektedir. Bu veriler, Hüseynî perdesinin eserlerin büyük çoğunluğunda güçlü perde konumunda olduğunun farklı yoldan sağlamasıdır. Toplam süreye oranı, kullanım sıklığı ve süresi bakımından üçüncü sırada yer alan Çargâh perdesi de üzerinde yapılan önemli kalışlarla birlikte makamın en etkin kullanılan perdelerinden birisidir. Çoğunlukla Arel-Ezgi nazariyesini temel alan, Kürdî makamının anlatıldığı güncel yazılı kaynaklarda makamın tek güçlü perdesi olarak ifade edilen, buna karşın MIDI analiz raporlarında tüm sütunlarda dördüncü sırada yer alan Neva perdesi, ezgi kalışlarında da Hüseynî ve Çargâh perdesinin biraz gerisinde kalmıştır. Etkinlik derecesi yüksek olan diğer bir perde de Kürdî perdesidir. Bu perde ezgi kalış bölgelerinde etkin kullanılmamasına karşın MIDI analiz raporlarında görüldüğü üzere 
eserler içerisinde fazlaca kullanılmıştır. İncelenen eserlerde kullanılan tüm perdelerin toplam süreye oranlarına bakıldığında dizinin ilk beş sesinin, toplam sürenin \% 84,86'sını kapsadığı görülmektedir. Bu da makamın genel seyir bölgesinin Dügâh-Hüseynî aral1ğında olduğunu göstermektedir.

Analiz edilen 20 eserin dizi kurulumlarına bakıldığında; 10 eserin (\%50) dizisinin yerinde Kürdî beşlisine Hüseynî perdesinde Kürdî üçlüsünün veya dörtlüsünün eklenmesinden; 5 eserin (\%25) dizisinin yalnızca yerinde Kürdî altılısından; 2 eserin (\%10) dizisinin yerinde Kürdî beşlisine Çargâh perdesinde Çargâh beşlisinin eklenmesinden; 1 eserin (\%5) dizisinin yerinde Kürdî dörtlüsüne Çargâh perdesinde Çargâh beşlisi ve Neva perdesinde Bûselik beşlisinin eklenmesinden; 1 eserin (\%5) dizisinin, yerinde Kürdî beşlisine Çargâh perdesinde Çargâh beşlisi ve Hüseynî perdesinde Kürdî üçlüsünün eklenmesinden; 1 eserin (\%5) dizisinin ise yerinde Kürdî beşlisine Çargâhta Pençgâh beşlisinin eklenmesinden oluştuğu görülmektedir. Bu verilerden hareketle, incelenen eserlerde en çok 'Kürdî beşlisine Kürdî dörtlüsünün eklendiği' dizinin kullanıldığı ve bazı eserlerin 'yalnızca Kürdî altılısından ibaret' olduğu görülmektedir. Dolayısıyla Arel-Ezgi nazariyesini temel alan veya Türk halk müziğinde makam dizilerine değinen hemen her kaynakta bildirildiği üzere; 'Kürdî makam dizisinin Kürdi dörtlüsüne Bûselik beşlisinin eklenmesiyle oluştuğu' bilgisi bu araştırma sonuçlarıyla örtüşmemektedir. Söz konusu kaynaklardan Özkan'ın Türk Mûsikîsi Nazariyatı ve Usûlleri isimli kitabında da Kürdî makam dizisi yukarıdaki gibi açıklanmakla birlikte; makam dizisinin bazen, özellikle de Kürdî makamı şedlerinde Kürdî beşlisine Kürdî dörtlüsünün eklenmesiyle oluştuğu notu da düşülmüştür (2013, s. 133). Yılmaz'ın TRT TSM repertuvarına kayıtlı şarkılar üzerinde yaptığı inceleme sonuçlarına göre de makam dizisi en çok Kürdî beşlisine Kürdî dörtlüsünün eklenmesiyle oluşturulmuştur (2019, s. 599). Bu araştırmada da sekiz sesli bir dizinin nasıl oluştuğu konusunda Yılmaz'ın çalışmasıyla benzer sonuçlar elde edilmiş; bunun yanı sıra altı, hatta bazen daha az sesten oluşan türkülerin makam kimliğinin oluşması için yeterli olduğu görülmüş̧ür. Dolayısıyla makamın var olabilmesi için en az sekiz sesli biz diziye ihtiyaç olmadığı düşünülmektedir. Zira bu türküleri dinleyen kişinin aklına Kürdî makamından başka bir makam gelmeyecektir.

İncelenen 20 eserin 13'ünde (\%65) güçlü, 'Hüseynî' perdesi; 4 eserde (\%20) Çargâh perdesi; 2 eserde (\%10) Neva perdesi ve 1 eserde (\%5) ise Muhayyer perdesidir. Güçlüsü Muhayyer perdesi olan söz konusu eser, seyir karakteri açısından da Kürdî makamına uymamaktadır ve bu araştırma verilerine göre de istisnai bir durumdadır. Bu verilere 
göre, güçlü perde konusunda da eserlerdeki durum Arel-Ezgi kuramını esas alan kaynaklarda ifade edilen bilgilerden farklıdır. Hüseynî perdesi dışında Çargâh ve Neva gibi perdelerin de güçlü perde konumunda olduğu eserler dikkate alınırsa Kürdî makamının güçlüsünün bazı eserlerde farklı olduğu görülmektedir. Bu durumda da Kürdî makamının, Arel-Ezgi nazariyesine göre basit makam tanımına da uymadığı söylenebilir.

Seyir karakteri açısından bakıldığında incelenen eserlerin 16'sının (\%80) inici-çıkıcı, 3'ünün (\%15) çıkıcı ve 1'inin de (\%5) inici seyirde olduğu tespit edilmiştir. Bu veriler yazılı kaynaklarla örtüşmektedir. Dizinin genişletilmesi hususunda da 20 eserin 18 'inde (\%90) dizinin genişletilmediği görülmektedir. Diğer 2 eserin birinde tiz taraftan yalnızca Sümbüle ve Tiz Bûselik perdelerine kadar çıkılmıştır. Diğer eserde ise pest taraftan Acem perdesinde Çargâh çeşnili bir genişleme ve tiz taraftan da yalnızda Sümbüle perdesinin alındığı bir genişleme söz konusudur.

Makamın en önemli unsurlarından biri olduğu düşünülen ezgi kalış bölgeleri ve çeşnileri açısından bakıldığında; incelenen 20 eserin hepsinde, doğal olarak, Dügâh perdesinde Kürdîli kalış yapıldığı görülmektedir. Bunun yanı sıra 16 eserde $\% 80$ oranla Hüseynî perdesinde Hüseynîli veya çeşnisiz; 8 eserde \%40 oranla Çargâh perdesinde Çargâhl1; 5 eserde Neva perdesinde Bûselikli; 1'er eserde \%5 oranla Acemaşiran perdesinde Çargâhl1, Rast perdesinde Bûselikli, Kürdî perdesinde TTT çeşnili, Çargâh perdesinde Pençgâhlı ve Muhayyer perdesinde çeşnisiz kalışlar yapılmıştır. Örnek türkülerden elde edilen bu veriler doğrultusunda, Dügâh perdesinde Kürdîli, Hüseynî perdesinde Kürdîli ve çeşnisiz, Çârgâh perdesinde Çârgâhlı ve Neva perdesinde Bûselikli kalışlar, Kürdî makamının önemli kalış yerleri ve çeşnileri olarak nitelendirilebilir.

Kalışların önem derecesi, güçlü perde ve dizinin oluşumu başta olmak üzere bazı konularda bu araştırma verileriyle Arel-Ezgi nazariyesini temel alan veya Türk halk müziğinde diziler konusuna değinen hemen her kaynaktaki Kürdî makamı ile ilgili bilgilerin önemli ölçüde farklılık gösterdiği; Yılmaz'ın bulgularının ise büyük oranda benzerlik taşıdığı söylenebilir (2019, s. 114). Bu sebeple, müzik eğitim kurumları başta olmak üzere çeşitli kurum ve kuruluşlar, akademisyenler ve besteciler tarafindan referans kabul edilen Arel-Ezgi kuramının birçok çalışmada ifade edilen eksiklikleri kabul edilip Türk makam müziğini bütün olarak ele alıp tam anlamıyla açıklayabilen nazari model önerileri üzerinde çalışılması çok önemlidir. Çünkü makam, perde, ses sistemi vb. konuların Türk müzik kuramı açısından önemi ortadır. 
Hakem Değerlendirmesi: Dış bağımsız.

Çıkar Çatışması: Yazar çıkar çatışması bildirmemiştir.

Finansal Destek: Yazar bu çalışma için finansal destek almadığını beyan etmiş̧ir.

Peer-review: Externally peer-reviewed.

Conflict of Interest: The author has no conflict of interest to declare.

Grant Support: The author declared that this study has received no financial support.

\section{Kaynakça/References}

Bayraktarkatal, M. E. ve Öztürk, O. M. (2012). Ezgisel kodların belirlediği bir sistem olarak makam kavramı: Hüseyni makamının incelenmesi. Porte Akademik Müzik ve Dans Araştırmaları Dergisi, 3(4), 24-59. Erişim adresi: http://porteakademik.itu.edu.tr/

Can, C. (2002). Geleneksel Türk sanat müziğinde Arel-Ezgi-Uzdilek ses sistemi ve uygulamada kullanılmayan bazı perdeler. Gazi Eğitim Fakültesi Dergisi. Cilt 22, 1, 175-181. Erişim adresi: https://dergipark.org.tr/tr/

Güray, C. (2017). Bin yılın mirası, makamı var eden döngü: Edvar geleneği. İstanbul: Pan Yayınc1lık.

İrden, S. (2015). Bileşik makam Bûselik. Rast Müzikoloji Dergisi. Cilt III, 2, 813-827. doi:10.12975/ rastmd.2015.03.02.00038

İrden, S. (2020). Türk musıkisinde düzen perde makam terkib uygulamalarl. Konya: Eğitim Yayınevi.

Kutluğ, Y. F. (2000). Türk mûsikîsinde makamlar. İstanbul: Yapı Kredi Yayınları.

Özbek, A. M. (1987). Türk halk müziğinde ayak tabirinin yanlış kullanımı üzerine. III. Milletlerarası Türk Folklor Kongresi Bildirileri, Cilt 3, 205-212.

Özek, E. (2014). 20. Yüzyıl Türk müziği icrasında perde anlayışı. İstanbul: Türk Musikisi Vakfı.

Özkan, İ. H. (2013). Türk mûsikîsi nazariyatı ve usulleri-Kudüm velveleleri (12. bs.). İstanbul: Ötüken Neşriyat A.Ş.

Öztürk, O. M., Beşiroğlu, Ş. ve Bayraktarkatal, M. E. (2014). Makamı anlamak: Makam nazariye tarihinde başlıca modeller. Porte Akademik, Cilt I, 10, 9-36. Erişim adresi: http://porteakademik.itu.edu.tr/

Öztürk, O. M. (2014a). Makam müziğinde ezgi ve makam ilişkisinin analizi ve yorumlanması açısından yeni bir yaklaşım: Perde düzenleri ve makamsal ezgi çekirdekleri (Yayınlanmamış Doktora Tezi). İstanbul Teknik Üniversitesi Sosyal Bilimler Enstitüsü, İstanbul.

Öztürk, O. M. (2014b). Makam, avaze, şube ve terkib: Osmanlı musiki nazariyatında Pisagorcu 'kürelerin uyumu/ musikisi’ anlayışının temsili. Rast Müzikoloji Dergisi, Cilt II, 1, 1-49. Erişim adresi: https://dergipark.org.tr/tr/

Öztürk, O. M. (2015). Halk mûsikîsi repertuar incelemelerinin makam nazariyesi araştırmalarına yapabileceği katk1lar. Ë̈ Devlet Türk Musikisi Dergisi. 2015(7), 1-27. Erişim adresi: https://dergipark.org.tr/tr/

Soysal, F. ve Yürümez, E. (2020). Türk halk müziği solfeji 1. Ankara: Nobel Akademik Yayıncılık.

Tura, Y. (2006). Tedkîk ü tahkîk / İnceleme ve gerçeği araştırma. İstanbul: Pan Yayıncılık

Tura, Y. (2017). Türk mûsikîsinin mes'eleleri (3. bs.). İstanbul: İz Yayınc1lık.

Uçan, A. (2015). Türk müzik kültürü, Ankara: Evrensel Müzik Yayın Evi.

Yarman, O. (2008). Türk makam müziği tarihinde ses sistemleri. İTÜ 2007-2008 Güz Dönemi Seminerleri. İstanbul Teknik Üniversitesi, İstanbul. 
Yılmaz, K. (2019). Arel nazariyatındaki basit makamlarda bestelenmiş klasik Türk müziği eserleri ile bu makamlara ait nazari bilgilerin bilgisayar destekli karşılaştırılması (Yayınlanmamış Sanatta Yeterlik Tezi). Sivas Cumhuriyet Üniversitesi Sosyal Bilimler Enstitüsü, Sivas.

Yılmaz, K. (2020). Arel-Ezgi-Uzdilek ses sistemi üzerine. Rast Müzikoloji Dergisi. Cilt 8, 1, 2348-2365. Erişim adresi: https://dergipark.org.tr/tr/

Zeren, A. (2003). Müzik sorunlarımız üzerine araştırmalar. İstanbul: Pan Yayıncılık. 